\title{
An Investigation on the Monetary Policy and Short-term Interest Rates in Japan
}

\author{
Chikashi Tsuji \\ Graduate School of Systems and Information Engineering, University of Tsukuba \\ 1-1-1 Tennodai, Tsukuba, Ibaraki 305-8573, Japan \\ E-mail:mail_sec_low@minos.ocn.ne.jp
}

Received: June 05, 2011 Accepted: June 07, 2011 DOI: 10.5296/jpag.v1i1.703

\begin{abstract}
We explore the inter-temporal linkage between call rate changes, consumer price index (CPI) changes, and real gross domestic product (GDP) changes in Japan based on the Taylor rule of monetary policy. In our analysis, we consider two sample periods, namely, the former is before zero-interest rate policy and the latter is after it. According to our empirical results, first, we find that the relations between call rate changes and GDP changes and those between call rate changes and CPI changes are weak before zero-interest rate policy. Second, we also find that after zero-interest rate policy, mutual inter-temporal relations between call rate changes and GDP changes are seen as the US Taylor rule suggests, although the linkage between call rate changes and CPI changes is not seen. Hence after zero-interest rate policy, regarding call rates and GDP, the relations suggested by US Taylor rule are found in Japan.
\end{abstract}

Keywords: Monetary policy, Taylor rule, Call rate. 


\section{Introduction}

In the fields of macroeconomics and finance, the linkage between macroeconomic factors and the term structure of interest rates is recently further analyzed by using rich data. (e.g. Ang and Piazzesi (2003), Diebold et al. (2006), Ludvigson and Ng (2009), Moench (2008), and Stock and Watson (2002))

On the other hand, in monetary economics, Taylor rule suggests the relations between interest rates and the specific macroeconomic variables from the viewpoints of monetary policy. (e.g. Ball (1999), Orphanides (2003), Svensson (1997), Taylor (1993), Taylor (1999). Also related literatures are Bernanke and Woodford (1997), Bernanke et al. (1999), Eggertsson and Woodford (2003), Friedman (1968), Hoshi and Kashyap (2004), Krugman (1998), Kuttner and Posen (2001), Romer (1992), Sargent and Wallace (1975), Staiger et al. (1997), Svensson (2001).) Namely, in Taylor rule, interest rates are related with the states of inflation rates and gross domestic products (GDP).

Using many data sometimes lead to noisy results, hence in this paper, we focus on the Taylor rule. More specifically, our objective of this paper is to carefully examine the linkage between short-term interest rates, consumer price index (CPI), and GDP in Japan by using two sample periods that are before zero-interest rate policy and after it.

The contribution of this paper is as follows. First, we find that in Japan, the relations between call rate changes and GDP changes and those between call rate changes and CPI changes are weak before zero-interest rate policy.

Second, we find that after zero-interest rate policy, mutual inter-temporal relations between call rate changes and GDP changes are seen as the US Taylor rule indicates. However, linkage between call rate changes and CPI changes is not seen. Therefore, after zero-interest rate policy, regarding call rates and GDP, the relations suggested by US Taylor rule are found in Japan.

Furthermore, our VAR model lags become shorter in the period after zero-interest rate policy; hence this suggests that after zero-interest rate policy, autoregressive relations of variables become weak. Also, our results indicate that the mutual relations, in particular, between call rates and GDP become stronger in Japan.

The rest of the paper is organized as follows. Section 2 introduces the Taylor rule, Section 3 describes the data we use, Section 4 describes the models, Section 5 demonstrates our empirical results, and Section 6 concludes the paper.

\section{Taylor Rule}

Taylor (1993) suggests that US monetary policy determines the interest rates by considering the situation of inflation rates and GDP growth rates. Romer (2005) describes the Taylor rule as the contemporaneous relations among interest rates, CPI, and GDP by using the linear equation. Considering this Taylor rule relationships, we carefully analyze the inter-temporal linkage among these three variables by using the standard VAR model. 


\section{Data}

Our full sample period is from the fourth quarter of 1985 to the fourth quarter of 2009. All data are from Nikkei Economic Electronic Databank System, and we divide the above sample period by considering the beginning of the Japanese zero-interest rate policy in February 1999. As a result, our first half sample period is from the fourth quarter of 1985 to the fourth quarter of 1996, and the latter half period is the second quarter of 1997 to the fourth quarter of 2009. As to the notations, CALL denotes the uncollateralized overnight call rates, DCALL means the first difference of CALL, GDP denotes the seasonally-adjusted real GDP, DGDP means the first difference of GDP, CPI denotes the seasonally-adjusted CPI (excluding food (excluding alcoholic beverages) and energy), and DCPI (DDCPI) means the first (second) difference of CPI.

First, we show the results of the Augmented Dickey-Fuller (ADF) unit root tests in Table 1. Table 1 indicates that CALL, GDP, and CPI have unit roots. Further, as to CALL and GDP, the first differences of these variables do not have unit roots, however, regarding CPI in the first half period, we should take the second difference of CPI because DCPI has a unit root.

Table 1. Results of the Unit Root Tests

\begin{tabular}{|c|c|c|c|c|c|c|c|}
\hline \multicolumn{8}{|c|}{ to the Fourth Quarter of 1996} \\
\hline & & CALL & DCALL & GDP & DGDP & CPI & DDCPI \\
\hline With & $t$-value & -0.256 & $-5.096 * * *$ & -1.473 & $-7.115 * * *$ & -1.425 & $-11.856 * * *$ \\
\hline constant & $p$-value & 0.923 & 0.000 & 0.538 & 0.000 & 0.561 & 0.000 \\
\hline With trend & $t$-value & -1.308 & $-9.559 * * *$ & -1.075 & $-7.386^{* * *}$ & -0.613 & $-11.753 * * *$ \\
\hline and constant & $p$-value & 0.872 & 0.000 & 0.922 & 0.000 & 0.973 & 0.000 \\
\hline \multicolumn{8}{|c|}{ Panel B } \\
\hline & & CALL & DCALL & GDP & DGDP & $\mathrm{CPI}$ & DCPI \\
\hline With & $t$-value & -2.398 & $-9.689 * * *$ & -1.093 & $-5.532 * * *$ & -0.189 & $-7.279 * * *$ \\
\hline constant & $p$-value & 0.148 & 0.000 & 0.712 & 0.000 & 0.933 & 0.000 \\
\hline With trend & $t$-value & -2.388 & $-9.684 * * *$ & -1.299 & $-5.499 * * *$ & -2.053 & $-7.082 * * *$ \\
\hline and constant & $p$-value & 0.381 & 0.000 & 0.877 & 0.000 & 0.558 & 0.000 \\
\hline
\end{tabular}

The results of the Augmented Dickey-Fuller unit root tests are displayed. The null hypothesis is that the variable has a unit root. ${ }^{* * *}$ rejects the null hypothesis at the $1 \%$ statistical significance level.

\section{Model}

In order to investigate the inter-temporal relationships among call rates, CPI, and GDP, this paper uses the VAR model. More specifically, for the first half of our full sample period, we use the following VAR model from (1) to (3).

$$
\begin{aligned}
& D C A L L_{t}=v+\sum_{k=1}^{m} \vartheta_{k} D C A L L_{t-k}+\sum_{k=1}^{m} \phi_{k} D G D P_{t-k}+\sum_{k=1}^{m} \delta_{k} D C P I_{t-k}+\tau_{t}, \\
& D G D P_{t}=\mu+\sum_{k=1}^{m} \lambda_{k} D C A L L_{t-k}+\sum_{k=1}^{m} \xi_{k} D G D P_{t-k}+\sum_{k=1}^{m} \rho_{k} D C P I_{t-k}+\omega_{t},
\end{aligned}
$$




$$
D D C P I_{t}=\alpha+\sum_{k=1}^{m} \gamma_{k} D C A L L_{t-k}+\sum_{k=1}^{m} \eta_{k} D G D P_{t-k}+\sum_{k=1}^{m} \psi_{k} D D C P I_{t-k}+\kappa_{t} \text {, }
$$

where model lag $m$ is determined as three by the Akaike's Information Criterion (AIC). Also, for the latter half sample period, DCPI is used for the VAR model as following equation (4) instead of equation (3), and lag $m$ is determined as one by AIC for the latter half period.

$$
D C P I_{t}=\alpha+\sum_{k=1}^{m} \gamma_{k} D C A L L_{t-k}+\sum_{k=1}^{m} \eta_{k} D G D P_{t-k}+\sum_{k=1}^{m} \psi_{k} D C P I_{t-k}+\kappa_{t} .
$$

\begin{tabular}{|c|c|c|c|c|c|c|}
\hline \multicolumn{7}{|c|}{ Panel A Sample Period of the Fourth Quarter of 1985 to the Fourth Quarter of 1996} \\
\hline & \multicolumn{2}{|c|}{ DCALL } & \multicolumn{2}{|c|}{ DGDP } & \multicolumn{2}{|c|}{ DDCPI } \\
\hline & Coef. & $t$-value & Coef. & $t$-value & Coef. & $t$-value \\
\hline DCALL $(-1)$ & $-0.502 * *$ & -3.052 & 827.082 & 0.896 & 0.008 & 0.149 \\
\hline DCALL $(-2)$ & 0.099 & 0.599 & 1422.710 & 1.533 & -0.058 & -1.139 \\
\hline DCALL $(-3)$ & -0.085 & -0.572 & -646.626 & -0.775 & -0.013 & -0.278 \\
\hline $\operatorname{DGDP}(-1)$ & $4.40 \mathrm{E}-05$ & 1.365 & -0.151 & -0.838 & $1.84 \mathrm{E}-05^{*}$ & 1.843 \\
\hline DGDP $(-2)$ & $3.16 \mathrm{E}-05$ & 0.986 & -0.008 & -0.044 & $2.18 \mathrm{E}-05^{* *}$ & 2.194 \\
\hline DGDP $(-3)$ & $6.30 \mathrm{E}-05^{*}$ & 1.945 & $0.434 * *$ & 2.393 & $-1.84 \mathrm{E}-06$ & -0.184 \\
\hline DDCPI $(-1)$ & -0.237 & -0.416 & 481.898 & 0.151 & $1.063 * *$ & 6.040 \\
\hline DDCPI $(-2)$ & 0.976 & 1.265 & -3600.433 & -0.832 & $-0.438^{*}$ & -1.835 \\
\hline DDCPI $(-3)$ & -0.714 & -1.330 & 2427.722 & 0.806 & 0.274 & 1.649 \\
\hline Constant & -0.610 & -1.561 & 3276.539 & 1.495 & -0.078 & -0.647 \\
\hline Adj. $R^{2}$ & \multicolumn{2}{|c|}{0.251} & \multicolumn{2}{|c|}{0.158} & \multicolumn{2}{|c|}{0.726} \\
\hline $\mathrm{AIC}$ & & & \multicolumn{2}{|c|}{22.099} & & \\
\hline \multicolumn{3}{|l|}{ Observations } & \multicolumn{2}{|c|}{45} & & \\
\hline \multicolumn{7}{|c|}{ Sample Period of the Second Quarter of 1997 to the Fourth Quarter of 2009} \\
\hline & \multicolumn{2}{|c|}{ DCALL } & \multicolumn{2}{|c|}{ DGDP } & \multicolumn{2}{|c|}{ DCPI } \\
\hline & Coef. & $t$-value & Coef. & $t$-value & Coef. & $t$-value \\
\hline DCALL $(-1)$ & $-0.411 * *$ & -3.065 & $15173.40^{* *}$ & 2.475 & -0.044 & -0.319 \\
\hline $\operatorname{DGDP}(-1)$ & $6.31 \mathrm{E}-06^{* *}$ & 2.073 & 0.116 & 0.831 & $1.79 \mathrm{E}-06$ & 0.569 \\
\hline DCPI $(-1)$ & -0.041 & -0.545 & -2762.885 & -0.809 & $0.488 * *$ & 6.341 \\
\hline Constant & -0.018 & -0.928 & 513.527 & 0.571 & $-0.065^{* *}$ & -3.210 \\
\hline Adj. $R^{2}$ & \multicolumn{2}{|c|}{0.147} & \multicolumn{2}{|c|}{0.118} & \multicolumn{2}{|c|}{0.437} \\
\hline AIC & & & \multicolumn{2}{|c|}{18.013} & & \\
\hline Observations & \multicolumn{6}{|c|}{51} \\
\hline
\end{tabular}

Table 2. VAR Estimation Results on Call Rate, GDP, and CPI 


\section{Empirical Results}

The estimation results of VAR are displayed in Table 2. Panel A of Table 2 shows that 1) the relations between call rate changes and GDP changes and those between call rate changes and CPI changes are weak. Hence before zero-interest rate policy, the linkage suggested by US Taylor rule is not seen in Japan. On the other hand, 2) the one-way effects that GDP growth leads to CPI increases are seen before zero-interest rate policy in Japan.

Next, Panel B of Table 2 indicates that after zero-interest rate policy, 1) the statistically significant mutual inter-temporal linkage between call rate changes and GDP changes is seen as the US Taylor rule suggests. However, relations between call rate changes and CPI changes cannot be seen. Thus after zero-interest rate policy, regarding call rates and GDP, the relations suggested by US Taylor rule are found in Japan. Further, 2) the one-way effects from GDP growth to CPI, which are seen in the first half period, disappear after zero-interest rate policy in Japan.

Furthermore, VAR model lags are longer in the period before zero-interest rate policy (Panel A of Table 2), hence we understand that after zero-interest rate policy, autoregressive relations of variables become weak and mutual relation, in particular, between call rates and GDP becomes stronger in Japan (Panel B of Table 2).

\section{Summary and Conclusions}

This paper examined the inter-temporal linkage between the call rate changes, CPI changes, and GDP changes in Japan based on the Taylor rule.

Our interesting findings and contributions are as follows. First, we find that before zero-interest rate policy, the relations between call rate changes and GDP changes and those between call rate changes and CPI changes are weak. Thus before zero-interest rate policy, the linkage suggested by US Taylor rule cannot be found in Japan.

Second, we also find that after zero-interest rate policy, mutual inter-temporal relations between call rate changes and GDP changes are seen as the US Taylor rule indicates, although the linkage between call rate changes and CPI changes is not seen. Therefore, after zero-interest rate policy, as to call rates and GDP, the relations suggested by US Taylor rule are found in Japan.

Further, VAR model lags become shorter in the period after zero-interest rate policy; hence this suggests that after zero-interest rate policy, variable autoregressive relations become weak. Our results show that the mutual relation, in particular, between call rates and GDP becomes stronger in Japan.

We consider that researches on the linkage between interest rates and macroeconomic dynamics are important, thus future researches based on certain theories or specific concepts, such as Taylor rule, are valuable all over the world to deepen our understanding on the linkage between macro-economy and financial markets. Further extension of the study exhibited in this paper is our future task. 


\section{Acknowledgement}

The author thanks the Japan Society for the Promotion of Science for the generous financial assistance for our research. Furthermore, I greatly thank the paper invitation from the Editor of this Journal.

\section{References}

Ang, A., \& Piazzesi, M. (2003). A no-arbitrage vector autoregression of term structure dynamics with macroeconomic and latent variables. Journal of Monetary Economics, 50, 745-787.

Ball, L. (1999). Efficient Rules for Monetary Policy. International Finance, 2, 63-83.

Bernanke, B. S., \& Woodford, M. (1997). Inflation Forecasts and Monetary Policy. Journal of Money, Credit, and Banking, 29, 653-684.

Bernanke, B. S., Laubach, T., Mishkin, F. S., \& Posen, A. S. (1999). Inflation Targeting: Lessons from the International Experience. Princeton, NJ: Princeton University Press.

Diebold, F. X., Rudebusch, G. D., \& Aruoba, S. B. (2006). The Macroeconomy and the Yield Curve: A Dynamic Latent Factor Approach. Journal of Econometrics, 131, 309-338.

Eggertsson, G., \& Woodford, M. (2003). The Zero Bound on Interest Rates and Optimal Monetary Policy. Brookings Papers on Economic Activity, 1, 139-233.

Friedman, M. (1968). The Role of Monetary Policy. American Economic Review, 58, 1-17.

Hoshi, T., \& Kashyap, A. K. (2004). Japan's Financial Crisis and Economic Stagnation. Journal of Economic Perspectives, 18, 3-26.

Krugman, P. R. (1998). It's Baaack: Japan's Slump and the Return of the Liquidity Trap. Brookings Papers on Economic Activity, 2, 137-205.

Kuttner, K. N., \& Posen, A. S. (2001). The Great Recession: Lessons for Macroeconomic Policy from Japan. Brookings Papers on Economic Activity, 2, 93-185.

Ludvigson, S. C., \& Ng, S. (2009). Macro Factors in Bond Risk Premia. Review of Financal Studies, 22, 5027-5067.

Moench, E. (2008). Forecasting the yield curve in a data-rich environment: A no-arbitrage factor-augmented VAR approach. Journal of Econometrics, 146, 26-43.

Orphanides, A. (2003). The Quest for Prosperity without Inflation. Journal of Monetary Economics, 50, 605-631.

Romer, C. D. (1992). What Ended the Great Depression? Journal of Economic History, 52, 757-784.

Romer, D. (2005). Advanced Macroeconomics. New York: MacGraw-Hill Companies, Inc.

Sargent, T. J., \& Wallace, N. (1975). 'Rational Expectations,' the Optimal Monetary Instrument, and the Optimal Money Supply Rule. Journal of Political Economy, 83, 241-254.

Staiger, D., Stock, J. H., \& Watson, M. W. (1997). How Precise Are Estimates of the Natural Rate of Unemployment? In C. D. Romer, \& D. H. Romer (Eds.), Reducing Inflation: Motivation and Strategy. Chicago: University of Chicago Press. pp. 195-242. 


\section{Macrothink}

Journal of Public Administration and Governance

ISSN 2161-7104

2011, Vol. 1, No. 1

Stock, J. H., \& Watson M. W. (2002). Macroeconomic forecasting using diffusion indexes. Journal of Business \& Economic Statistics, 20, 147-162.

Svensson, L. E. O. (1997). Inflation Forecast Targeting: Implementing and Monitoring Inflation Targets. European Economic Review, 41, 1111-1146.

Svensson, L. E. O. (2001). The Zero Bound in an Open Economy: A Foolproof Way of Escaping from a Liquidity Trap. Monetary and Economic Studies, 19, 277-312.

Taylor, J. B. (1993). Discretion versus Policy Rules in Practice. Carnegie-Rochester Conference Series on Public Policy, 39, 195-214.

Taylor, J. B., Ed. (1999). Monetary Policy Rules. Chicago: University of Chicago Press. 